\title{
Permasalahan Perbedaan Luas Tanah Antara Letter $C$ dengan Hasil Pengukuran Pada Pendaftaran Tanah Pertama Kali
}

\author{
Ignatius Harun Natadiarta, Nabitatus Sa'adah, Anggita Doramia Lumbanraja \\ Program Studi Magister Kenotariatan \\ Fakultas Hukum, Universitas Diponegoro \\ Email : ihn494@gmail.com
}

\begin{abstract}
Land registration is applied under the Principal Provisions of Agrarian Law in Indonesia. It aims to provide legal certainty and protection for landowners. However, at the land registration process, there was the problem of difference in land area between Letter $\mathrm{C}$ and the measurement results by the Land Office. Not many previous studies addressed this problem. In addition, the government has not yet issued specific guidelines that can be used in solving the issues. Researchers conducted interviews and field observations, as well as secondary data collection related to land area differences. This study discusses the causes of land measurement disputes and their solutions in Semarang Regency. The problem of land area differences happened because the village apparatus did not carry out cadastral measurements and the technique was far from the principle of precision so that the results were often different from the measurements made by the Land Office using the principle delimitation contradictories principle and cadastral measurements with the latest measurement tools. In resolving this problem, the Semarang Regency Land Office will summon the applicant's, adjoining neighbors, and village chief into mediation to reach an agreement regarding the determination of the boundary and the measurement result of the requested land area.
\end{abstract}

Keywords : letter C, land measurement disputes

\begin{abstract}
Abstrak
Pendaftaran tanah dilakukan berdasarkan Undang-undang Pokok Agraria, yang bertujuan untuk memberikan kepastian hukum dan perlindungan bagi pemilik tanah. Akan tetapi pada saat dilakukan pendaftaran tanah di temukan permasalahan perbedaan luas tanah antara Letter $C$ dengan hasil ukur oleh Kantor Pertanahan. Belum banyak penelitian sebelumnya yang membahas mengenai permasalahan beda luas. Selain itu, pemerintah juga belum menerbitkan panduan khusus yang dapat digunakan sebagai pedoman dalam penyelesaian permasalahan. Peneliti melakukan wawancara dan observasi lapangan, serta pengumpulan data sekunder terkait permasalahan perbedaan luas tanah. Penelitian ini membahas mengenai penyebab terjadinya sengketa pengukuran tanah serta penyelesaiannya di Kabupaten Semarang. Permasalahan perbedaan luas tanah pada saat dilakukan pengukuran oleh Kantor Pertanahan disebabkan karena pada saat pembuatan Letter $C$ oleh perangkat desa tidak melakukan pengukuran kadastral dan teknik pengukurannya pun jauh dari asas presisi sehingga hasil dari pengukuran sering berbeda dengan hasil pengukuran yang dilakukan oleh Kantor Pertanahan yang menggunakan asas kontradiktur delimitasi dan melakukan pengukuran kadastral dengan alat ukur mutakhir. Dalam penyelesaian permasalahan ini, Kantor Pertanahan Kabupaten Semarang akan memanggil pemohon sertipikat, tetangga batas tanah, Kepala Desa dalam mediasi untuk mencapai kesepakatan mengenai penetapan batas bidang tanah dan hasil pengukuran luas tanah atas tanah tersebut.
\end{abstract}

Kata kunci : letter $C$, sengketa pengukuran tanah 


\section{A. Pendahuluan}

Undang-Undang Dasar 1945 pada pasal 33 ayat (3) memberikan landasan bahwa bumi, air serta segala yang terkandung didalamnya dikuasai oleh negara dan dipergunakan sebesarbesarnya untuk kemakmuran rakyat. Atas dasar inilah negara selaku badan penguasa diberi wewenang untuk menguasai, mengatur, mengurus, serta menyelesaikan segala persoalan yang berkenaan dengan fungsi tanah. Pentingnya tanah bagi kehidupan masyarakat untuk kebutuhan akan tempat tinggal, tempat berusaha sebagai sumber mata pencaharian, maka perlu penataan dan penertiban di bidang pertanahan agar fungsi tanah dapat dimanfaatkan oleh seluruh rakyat.(Undang-Undang Dasar 1945)

Salah satu tujuan dibentuknya UUPA adalah meletakan dasar-dasar dalam memberikan kepastian hukum mengenai hak atas tanah dan untuk memberikan kepastian hukum maka perlu dilaksanakan kegiatan pendaftaran tanah. (Undang-Undang Nomor 5 Tahun 1960 Tentang Peraturan Dasar Pokok-Pokok Agraria). Tujuan diadakannya pendaftaran tanah oleh pemerintah untuk memberi jaminan kepastian hukum. Oleh karena itu agar tercapai kepastian hukum dan kepastian hak atas tanah, maka bagi pemilik hak atas tanah harus mendaftarkan tanahnya supaya jelas siapa pemilik tanah yang sebenarnya. Aturan mengenai pendaftaran tanah termuat di dalam Peraturan Pemerintah (PP) Nomor 24 Tahun 1997 mengenai pendaftaran tanah.

Pendaftaran secara sporadik dilakukan atas permintaan secara individu atau berdasarkan kuasa yang di tujuk untuk melaksanakannya. Dalam prakteknya masyarakat lebih menggunakan pendaftaran tanah secara sporadik karena merasa perlu untuk segera mendaftarkan tanahnya dan jangka waktunya dapat diprediksikan. Pendaftaran tanah secara sporadik dapat dilakukan sendiri dengan datang ke Kantor Pertanahan atau dapat juga melalui Pejabat Pembuat Akta Tanah (PPAT).(Peraturan Pemerintah Nomor 24 Tahun 1997 Tentang Pendaftaran Tanah)

Pendaftaran tanah dilakukan berdasarkan Undang-Undang Nomor 5 Tahun 1960 tentang Peraturan Dasar Pokok-pokok Agraria (UUPA). Pasal 19 undang-undang ini memerintahkan diselenggarakannya pendaftaran atas tanah dalam rangka menjamin kepastian hukum. Pasal 19 undang-undang nomor 5 tahun 1960 (UUPA) mengamanahkan untuk melakukan pendaftaran tanah untuk menjamin kepastian hukum. 
Di dalam pasal 19 ayat (1) Undang-Undang Pokok Agraria (UUPA) dijelaskan bahwa penyelenggara pendaftaran tanah di seluruh wilayah Negara Kesatuan Republik Indonesia (NKRI) merupakan tanggung jawab pemerintah, tujuan diselenggarakannya pendaftaran tanah yang menyeluruh supaya memberikan perlindungan hukum dan kepastian hukum atas pemilik tanah yang masih belum memiliki hak atas tanah yang kuat.

Makna pasal 19 UUPA ini maka untuk menjamin kepastian hukum, oleh pemerintah diadakan pendaftaran tanah diseluruh wilayah Republik Indonesia dengan suatu peraturan pemerintah kepastian hukum yang menyangkut pertanahan mengenai pemilikan dan penguasaan tanah meliputi unsur-unsur kepastian terhadap subyek dan obyek hak atas tanah yaitu orang atau badan hukum yang menjadi pemegang hak dan kepastian mengenai letak, batas, dan luas tanah.

Selanjutnya pendaftaran tanah diatur melalui Peraturan Pemerintah Nomor 4 Tahun 1997 tentang Pendaftaran Tanah dan Peraturan Menteri Agraria atau Kepala Badan Pertanahan Nasional Nomor 3 Tahun 1997 Tentang Ketentuan Pelaksana Peraturan Pemerintah Nomor 24 Tahun 1997(Sangsun 2007).

Penelitian sebelumnya oleh (Silviana 2012) bertujuan untuk mendeskripsikan kesadaran masyarakat terhadap pendaftaran tanah. Hasil penelitian menggambarkan bahwa tingkat kesadaran warga Desa Notog masih rendah karena mereka hanya mengetahui isi aturan hukum namun tidak dilanjutkan dengan sikap dan perilaku yang sesuai dengan aturan hukum. Penelitian ini hanya membahas mengenai tingkat kesadaran masyarakat pada pentingnya pendaftaran tanah, belum menekankan pada permasalahan perbedaan luas. Peneliti (Anhar 2017) menjabarkan bahwa Penerapan asas aman dan terbuka pada Kantor Pertanahan Kabupaten Lombok Barat belum sesuai dengan apa yang diharapkan,dimana dalam pelaksanaan asas aman,pihak Kantor Kantor Pertanahan kurang teliti dan cermat dalam memperoses berkas data fisik maupun data yuridis dari pemohon, kemudian mengenai asas terbuka tidak dilakukannya keterbukaan informasi publik oleh pihak kantor pertanahan baik di kantor pertanahan sendiri maupun yang ada dikantor desa mengenai bidang tanah yang terdaftar, hal tersebut belum sesuai dengan apa yang diatur dalam Pasal 23 ayat (4) UndangUndang Nomor 25 Tahun 2009 tentang Keterbukaan Informasi. Di penelitian ini hanya membahas asas aman dalam pendaftaran tanah, dan belum membahas asas kontradiktur yang digunakan Kantor Pertanahan pada saat dilakukan pengukuran tanah. Penelitian lain oleh (Arief 2018) menitikberatkan pada asas yang digunakan oleh kantor pertanahan. (Arief 2018) meneliti mengenai pelaksanaan asas kontradiktur delimitasi dalam proses pendaftaran tanah sistematis lengkap. Kendala dapat terjadi jika asas kontradiktur delimitasi tidak dilaksanakan sesuai 
dengan aturan perundang-undangan, yang mana akan menimbulkan ketidakpastian hak seseorang atas kepemilikan suatu bidang tanah yang mengakibatkan sengketa dan dapat menimbulkan konflik pertanahan di kemudian hari.

Penelitian oleh (Arief 2018) dan penelitian yang akan dilakukan oleh peneliti sama-sama menggunakan asas kontradiktur delimitasi dalam proses pendaftaran tanah pertama kali, bedanya adalah penelitian oleh (Arief 2018) meneliti proses pendaftaran tanah secara sistematis lengkap, sedangkan peneliti akan membahas dalam proses pendaftaran tanah secara sporadik. Setelah mengkaji penelitian-penelitian terdahulu tersebut maka dapat disimpulkan bahwa penelitian yang akan dilakukan oleh peneliti berbeda, memiliki unsur kebaruan dan keorisinalitasan dari penelitian sebelumnya.

Berdasarkan uraian tersebut, peneliti merasa tertarik untuk mengkaji lebih lanjut berkaitan dengan permasalahan didalam pendaftaran tanah. Dari uraian di atas maka permasalahan yang dikaji dalam penelitian ini adalah mengenai faktor-faktor penyebab permasalahan perbedaan luas tanah di Kantor Pertanahan Kabupaten Semarang dan bagaimana upaya yang dilakukan Kantor Pertanahan Kabupaten Semarang apabila terjadi permasalahan perbedaan luas tanah.

\section{B. Metode Penelitian}

Dalam penelitian ini metode Pendekatan yang digunakan adalah pendekatan Empiris, dengan menggunakan metode penelitian empiris maka peneliti akan mengambil data primer dari hasil wawancara di Kantor Pertanahan Kabupaten Semarang, Kabupaten Semarang, Kantor Notaris, Pejabat Pembuat Akta Tanah RR. Arumdati Pratiwi, SH.M.kn di Kabupaten Semarang, Kantor Desa Leyangan. Bahan hukum sekunder yang penulis gunakan di dalam penulisan ini yakni: 1) Undang-Undang Nomor 5 Tahun 1960 tentang Peraturan Dasar PokokPokok Agraria. 2) Peraturan Pemerintah Republik Indonesia No 24 Tahun 1997 tentang Pendaftaran Tanah. 3) Peraturan Menteri Agraria atau Kepala Badan Pertanahan Nasional Nomor 3 Tahun 1997 Tentang Pelaksanaan Peraturan Pemerintah Nomor 24 Tahun 1997 tentang Pendaftaran Tanah.

\section{Hasil Penelitian Dan Pembahasan}

\section{Faktor Penyebab Permasalahan Perbedaan Luas Tanah Di Kantor Pertanahan}

Pendaftaran tanah berdasarkan ketentuan pasal 19 UUPA bertujuan untuk memberikan kepastian hak dan menjamin kepastian hukum hak atas tanah bagi seluruh masyarakat Indonesia (Handoko 2014), pendaftaran tanah dapat dilaksanakan secara sistematis maupun 
sporadik dan akan menghasilkan sertipikat sebagai tanda bukti hak yang berlaku sebagai alat bukti yang kuat. Berbagai faktor mempengaruhi minat masyarakat untuk mendaftarkan tanahnya secara sporadik. Pendaftaran secara sporadik dilaksanakan berdasarkan permintaan pihak yang berkepentingan yaitu pihak yang berhak atas obyek pendaftaran tanah yang bersangkutan atau kuasanya. (Sangsun 2007)

Yang menjadi faktor penyebab timbul permasalahan perbedaan luas dikarenakan karena luas Letter $\mathrm{C}$ yang digunakan dasar pembuktian kepemilikan tanah sebelum terbit sertipikat tanah tidak akurat karena pada saat dilakukan pengukuran tanah hanya menggunakan alat sederhana dan tidak menggunakan teknik kadastral. Metode pengukuran yang digunakan pada waktu pendataan tanah masih menggunakan meteran yang kurang akurat atau tanda batas-batas bidang tanah tidak berupa patok dari beton dan kurang paten, sehingga tanda batas tersebut dapat hilang ataupun bergeser. Dijelaskan oleh Kepala Seksi Pengukuran Tanah bahwa Letter C yang digunakan sebagai dasar pembuktian kepemilikan tanah sebelum terbit sertipikat merupakan produk lama sehingga saat dilakukan pengukuran pada saat pembuatan Letter C tidak menggunakan teknik pengukuran kadastral seperti yang dilakukan Kantor Pertanahan sehingga hasil yang didapat tidak akurat. Dan pada saat dilakukan pengukuran, tanda batas yang digunakan bukan patok beton seperti Kantor Pertanahan, melainkan tanda batas yang tidak paten sehingga dapat hilang maupun bergeser. Menurut penjelasan Kepala Seksi Pengukuran Tanah masalah perbedaan luas tanah sering muncul pada tahap penetapan batas dan pengukuran terhadap bidang tanah yang dimohonkan.

Kantor Pertanahan menyebutkan bahwa Letter C tidak dapat digunakan sebagai bukti kepemilikan atas tanah namun merupakan bukti awal dalam bentuk tertulis. Sekitar tahun 1813, Letter C yang merupakan bukti pembayaran pajak dapat digunakan sebagai bukti awal untuk mendapatkan hak atas tanah. Dalam proses pendaftaran tanah untuk pertama kali dari konversi hak lama (Letter C) sering kali ditemukan adanya perbedaan ukuran luas tanah yang tercantum dalam Letter $\mathrm{C}$ dengan hasil pengukuran dari Kantor Pertanahan. Penyebab perbedaan tersebut dikarenakan pada jaman dahulu pengukuran tanah masih menggunakan cara manual dengan menggunakan alat seadanya.

Dalam hal ini juga sering muncul kekurangan luas dalam ukuran tanah menjadi berkurang luas tanah yang tercantum dalam letter $\mathrm{C}$, berdasarkan wawancara dengan Notaris dan PPAT Dalam melakukan pendaftaran tanah Letter $C$ digunakan sebagai bukti awal saat melakukan pendaftaran pertama kali, Berdasarkan hasil wawancara dengan seketaris Desa Leyangan dikatakan Letter $C$ adalah sebuah dokumen desa berbentuk daftar yang memuat 
penjelasan tentang identitas pemilik yang berhak atas tanah dan yang membuat instansi terkait pada saat itu, untuk mengetahui tanah milik nya, jadi pada jaman dulu kepemilikan tanah hanya berdasar ingatan orang, belum ada surat tertulis yang digunakan sebagai bukti kepemilkan tanah, setelah ada aturan dari pemerintah jaman dulu maka setiap tanah di buatkan surat sebagai tanda bukti yang dinamakan Letter $C$.

Petuk pajak oleh pengadilan juga tidak diterima sebagai tanda bukti pemilikan tanah yang dikenakan pajak, dinyatakan dalam putusan makamah agung tanggal 10 februari 1960 nomor 34/K/Sip/1960, bahwa :

"Surat petuk pajak bumi bukan merupakan suatu bukti mutlak, bahwa sawah sengketa adalah milik orang yang namanya tercantum dalam petuk pajak bumi tersebut, akan tetapi petuk itu hanya merupakan suatu tanda siapakah yang harus membayar pajak dari sawah yang bersangkutan"

Ketiga pajak tanah tersebut pada tahun 1961 diganti dengan pungutan baru dengan nama Iuran Pembangunan Daerah (IPEDA). Lalu IPEDA kemudian diganti dengan pajak baru, yang diberi nama Pajak Bumi dan Bangunan (PBB) dengan adanya Undang-Undang Nomor 12 Tahun 1985 tentang Pajak Bumi dan Bangunan (PBB) (Harsono 2003).

Dalam pasal 11 Peraturan Pemerintah (PP) Nomor 24 Tahun 1997 pelaksanaan pendaftaran meliputi kegiatan pendaftaran tanah untuk pertama kali dan pemeliharaan data pendaftaran tanah. pendaftaran tanah untuk pertama kali adalah pendaftaran tanah yang dilakukan terhadap obyek pendaftaran tanah yang belum terdaftar, dengan kata lain pendaftaran tanah untuk pertama kali bersifat originalatau murni(Lubis and Lubis 2012). Berdasarkan wawancara dengan RR. Arumdati Pratiwi,S.H.,M.Kn. untuk melakukan pendaftaran tanah pertama kali guna mendapatkan sertipikat tanah, ada syarat-syarat dan tahapan yang telah ditetapkan oleh Kantor Pertanahan, yaitu dalam melakukan permohonan pendaftaran tanah untuk pertama kali, disarankan kepada pemohon untuk datang dan melakukan konsultasi di Kantor Pertanahan Kabupaten Semarang, supaya pemohon mengetahui syarat-syarat apa yang harus disertakan pada saat melakukan permohonan pendaftaran tanah. Hal ini bertujuan untuk memperlancar dalam melakukan permohonan pendaftaran tanah.

Jika tidak memiliki bukti kepemilikan atas bidang tanah sebagaimana dimaksud di atas, maka pemilik tanah dapat membuktikan kepemilikan atas bidang tanah dengan melengkapi bukti lain. Bukti tersebut berupa pernyataan bahwa yang bersangkutan adalah benar pemilik bidang tanah tersebut. Bukti ini dibuat oleh pemilik tanah dan kelurahan serta 
minimal dua orang saksi di lingkungan setempat yang tidak memiliki hubungan keluarga dengan pemilik tanah sampai derajat kedua, baik dalam kekerabatan vertical maupun horizontal. (Peraturan Menteri Negara Agraria Nomor 2 Tahun 1996 Tentang Pengukuran Dan Pemetaan Untuk Penyelenggaraan Pendaftaran Tanah)

Setelah dokumen dan syarat-syarat kegiatan pendaftaran tanah untuk pertama kali dilengkapi, maka selanjutnya akan dilakukan pengumpulan dan pengolahan data fisik. sesuai dengan pasal 14 ayat 1 untuk keperluan pengumpulan dan pengolahan data fisik dilakukan kegiatan pengukuran dan pemetaan. Kegiatan pengukuran dan pemetaan didahului dengan melihat peta dasar pendaftaran. Menurut Kepala Seksi Survei Pengukuran dan Pemetaan dari Kantor Pertanahan peta dasar pendaftaran adalah peta induk untuk mengetahui bidang tanah dan berfungsi memudahkan bagi pihak petugas pengukuran dari kantor pertanahan untuk mengetahui letak tanah dan status tanah tersebut.

Selanjutnya akan dilakukan penetapan batas bidang tanah untuk memperoleh data fisik yang diperlukan bagi pendaftaran tanah sesuai dengan pasal 17 Peraturan Pemerintah Nomor 24 Tahun 1997 ayat 1. Peraturan tersebut menyatakan bahwa untuk memperoleh data fisik yang diperlukan dalam proses pendaftaran tanah, bidang-bidang tanah akan diukur, kemudian akan dilakukan peletakan tanda batas di setiap sudut bidang tanah yang bersangkutan. Pada saat dilakukan penetapan batas dan pengukuran yang dilakukan petugas ukur, sering kali terjadi permasalahan perbedaan luas tanah hasil pengukuran dan luas tanah yang tertera dalam Letter C. (Santoso 2015)

Tabel 1. Analisa Perbedaan Luas Tanah

\begin{tabular}{clccc}
\hline No. & Kecamatan & Permasalahan Beda Luas & $\begin{array}{c}\text { Kekurangan } \\
\text { Luas }\end{array}$ & Kelebihan Luas \\
\hline 1 & Ungaran Barat & 3 & 2 & 1 \\
\hline 2 & Ungaran Timur & 3 & 0 & 3 \\
\hline 3 & Bergas & 12 & 1 & 2 \\
\hline 4 & Pringapus & 3 & 1 & 9 \\
\hline 5 & Bawen & 15 & 6 & 5 \\
\hline 6 & Tuntang & 6 & 1 & 1 \\
\hline 7 & Pabelan & 1 & 0 & 1 \\
\hline 8 & Susukan & 1 & 0 & 3 \\
\hline 9 & Tengaran & 1 & 1 & 1 \\
\hline 10 & Ambarawa & 4 & 1 & 0 \\
\hline 11 & Jambu & 1 & 0 & $\mathbf{3 7}$ \\
\hline 12 & Getasan & 2 & 2 & $\mathbf{1 5}$ \\
\hline
\end{tabular}

Sumber : Kantor Pertanahan Kabupaten Semarang, 2017

Setelah di jabarkan melalui tabel diketahui kelebihan luas sebanyak 37 kelebihan luas dan 15 kekurangan luas, sehingga dapat diketahui lebih banyak permasalahan kelebihan luas 
dibandingkan dengan kekurangan luas. Berdasarkan hasil wawancara dengan kepala seksi pengukuran tanah kantor pertanahan kabupaten semarang Yan Septi Dyas S.T., S.H., Selama tahun 2016 terdapat 209 permohonan pendaftaran tanah pertama kali di lingkungan Kantor Pertanahan Kabupaten Semarang. Di tahun 2016 banyak terjadi permasalahan mengenai perbedaan luas, pada saat pengukuran tanah terjadi permasalahan kelebihan luas lebih banyak dibandingkan kekurangan luas, rata-rata kelebihan luas $65 \%$ dan kekurangan luas 25\%. Terjadinya kelebihan luas tanah disebabkan karena masyarakat jaman dahulu ingin membayar pajak lebih murah dari seharusnya, dengan cara mengurangi jumlah luasan tanah dari yang sebenarnya.

Perbedaan luas tanah antara hasil pengukuran dan luas tanah yang tertera dalam Letter $C$ bisa disebabkan karena luas Letter $C$ yang digunakan sebagai dasar pembuktian kepemilikan tanah sebelum terbit sertipikat tanah kurang akurat, karena pada saat dilakukan pengukuran tanah hanya menggunakan alat sederhana dan tidak menggunakan teknik kadastral. Metode pengukuran yang digunakan pada waktu pendataan tanah pada pembuatan Letter $C$ masih manual menggunakan meteran yang kurang akurat dan tanda batas-batas bidang tanah tidak berupa patok dari beton atau kurang paten, sehingga tanda batas tersebut dapat hilang ataupun bergeser. Menurut penjelasan Kepala Seksi Pengukuran Tanah masalah perbedaan luas tanah sering muncul pada tahap penetapan batas dan pengukuran terhadap bidang tanah yang dimohonkan.

Pada saat dilakukan pengukuran yang dilakukan petugas ukur. Maka akan diketahui luas tanah yang dimohonkan. Menurut kenyataannya luas yang didapat setelah dilakukan pengukuran tenyata bisa terjadi kelebihan atau kekurangan luas. Hasil wawancara dengan Notaris dan PPAT yang menjelaskan faktor yang sering menjadi sebab kekurangan luas tanah dikarenakan dua hal penyebab yakni, Pertama, karena erosi tanah, yakni parit terkikis oleh air dan mengakibatkan volume parit melebar dan luas tanah menjadi berkurang. Kedua, karena tanda batas berupa jalan, kekurangan luas tersebut dikarenakan toleransi pemilik hak atas tanah cukup tinggi dengan memberikan jalan pertolongan bagi tetangga sekitarnya dan tidak memikirkan akibat akan membuat kerugian bagi dirinya. Dalam hal ini pihak yang dirugikan adalah dirinya sendiri masalah ini akan terjadi kekurangan luas

Hasil pengukuran tanah berdasarkan Letter $C$ lebih kecil daripada hasil pengukuran menggunakan alat deodolit (Global Positioning System) oleh Kantor Pertanahan Kabupaten Semarang, disebabkan kecenderungan masyarakat yang enggan membayar pajak yang tinggi. Kebijakan Sunset Policy tahun 2008 dan program Tax Amesty tahun 2016 semakin menguatkan argumen bahwa masyarakat Indonesia tidak suka membayar pajak. 
Dalam perbedaan luas tanah juga ditemukan kekurangan luas tanah, hal ini disebabkan karena erosi tanah akibat dari alam yang menyebabkan tanah tergerus oleh air sehingga luas tanah semakin lama semakin berkurang. hal ini menyebabkan saat dilakukan pengukuran tanah oleh Kantor Pertanahan Kabupaten Semarang luas yang tertera di Letter $C$ lebih sedikit dibandingkan luas hasil pengukuran menggunakan alat dari Kantor Pertanahan. Hal lain yang menyebabkan kekurangan luas ialah tanda batas berupa akses jalan, karena pada jaman dahulu tiap tetangga sudah saling mengenal satu dengan lain nya dan toleransi pemilik tanah yang cukup tinggi sehingga dengan rela mengurangi luas tanah untuk dipakai sebagai jalan.

\section{Upaya Yang Dilakukan Kantor Pertanahan Kabupaten Semarang Apabila Terjadi Permasalahan Perbedaan Luas Tanah.}

Pendaftaran tanah merupakan upaya pemerintah untuk menjamin kepastian hukum pemegang hak atas tanah agar mendapat tanda bukti yang kuat, dengan mendaftarkan tanah nya masyarakat telah membantu pemerintah untuk menata kembali tanah-tanah yang tidak memiliki kepemilikan. Dalam pasal 3 Peraturan Pemerintah Nomor 24 Tahun 1997, Pendaftaran tanah untuk pertama kali atas suatu bidang tanah dilakukan agar mendapat kepastian hukum bagi pemegang hak atas tanah maupun pihak lain yang berkepentingan dengan tanah.

Seperti yang telah diketahui di dalam pendaftaran tanah ditemukan permasalahan perbedaan luas tanah antara hasil pengukuran lapangan yang dilakukan petugas ukur dari Kantor Pertanahan Kabupaten Semarang dengan luas yang tertulis di Letter C. Kantor Pertanahan Kabupaten Semarang dalam pelaksanaan pendaftaran pertama kali sering berhadapan dengan permasalahan perbedaan luas tanah. Dari wawancara dengan Notaris dan Pejabat Pembuat Akta Tanah (PPAT) Kabupaten Semarang RR.Arumdati Pratiwi, S.H.,M.kn. menjelaskan bahwa jika didalam pendaftaran tanah saat dilakukan pengukuran tanah ditemukan perbedaan luas lebih dari sepuluh persen (10\%) maka akan dilakukan pemanggilan mediasi kepada pemohon sertipikat dan para pihak yang bersangkutan untuk mengklarifikasi permasalahan perbedaan luas yang terjadi.

Hal tersebut dikuatkan dengan hasil wawancara dengan Kepala Seksi Pengukuran Tanah Kantor Pertanahan Kabupaten Semarang Yan Septi Dyas, S.T.,S.H. yang juga menjelaskan petugas pengukuran dari Kantor Pertanahan Kabupaten Semarang akan memanggil pemohon sertipikat, tetangga batas tanah, dan Kepala Desa kedalam mediasi untuk mencapai kesepakatan mengenai penetapan batas bidang tanah dan hasil pengukuran 
luas tanah atas tanah yang dimohonkan tersebut. Untuk penyelesaian perbedaan luas tanah dimana perbedaan luas tersebut terjadi kelebihan luas ataupun kekurangan luas sepuluh persen (10\%) dari luas yang tercantum dalam surat tanda bukti hak milik sementara, pihak Kantor Pertanahan dan Kantor Kelurahan tidak mempermasalahkan itu akan tergantung dari kesepakatan pihak pemegang hak atas tanah yang bersangkutan dengan pemegang hak atas tanah yang berbatasan. Selain itu harus dilakukan pengawasan supaya dapat diketahui bahwa proses sudah sesuai dengan yang semestinya atau tidak. Pengawasan merupakan pengamatan seluruh kegiatan untuk menjamin seluruh kegiatan berjalan dengan rencana. (handoko 2019)

Setelah masing-masing pihak yang bersangkutan menandatangani surat pernyataan bahwa mereka menerima perbedaan luas dan proses pendaftaran tanah dapat dilanjutkan. setelah itu dapat terbit peta bidang tanah, dari peta bidang dapat dilanjutkan ke permohonan konversi yang merupakan sidang pantiaadjudikasi untuk mencari kebenaran data fisik dan yuridis, pada sidang panitia adjudikasi pihak dari Kantor Pertanahan akan datang ke kelurahan untuk memberi catatan pada Letter $C$ bahwa tanah tersebut telah bersertipikat, Setelah itu dilakukan sidang panitia adjudikasi yang mana pihak dari Kantor Pertanahan beserta Pejabat Pembuat Akta Tanah (PPAT) akan datang ke kantor kelurahan tempat daerah pemohon sertipikat untuk menandai di Letter $C$ bahwa telah berganti tanda bukti kepemilikan tanah menjadi sertipikat hak atas tanah.(Peraturan Kepala BPN RI Nomor 1 Tahun 2010 Tentang Standar Pelayanan Dan Pengaturan Pertanahan)

Setelah sampai di tahap pengumuman maka Kantor pertanahan akan memajang dipapan pengumuman untuk data-data hasil permohonan hak dan memberi waktu selama 60 (enam puluh) hari kepada masyarakat, dan jika tidak ada keberatan maka terbit sertipikat hak atas tanah. Penerbitan sertipikat merupakan hasil akhir kegiatan pendaftaran tanah secara $\operatorname{sporadik}($ Fea 2016).

\section{Simpulan}

Berdasarkan hasil penelitian, permasalahan perbedaan luas tanah pada saat dilakukan pengukuran oleh Kantor Pertanahan dapat disebabkan karena luas yang tertulis di Letter C desa yang digunakan sebagai acuan dalam pengukuran tanah untuk pendaftaran tanah pertama kali tidak sama dengan hasil pengukuran yang dilakukan oleh Kantor Pertanahan, hal ini disebabkan karena pada saat dahulu pembuatan Letter $C$ desa perangkat desa tidak melakukan pengukuran kadastral dan teknik pengukuran nya pun jauh dari asas presisi sehingga hasil dari pengukuran sering berbeda dengan hasil pengukuran yang dilakukan oleh Kantor Pertanahan 
yang melakukan pengukuran kadastral yang berpegang pada asas kontradiktur delemitasi yang wajib di patuhi pada saat dilakukan pengukuran, asas ini untuk menghadirkan pemilik tanah tetangga batas dengan pemilik tanah yang dimohonkan. Faktor lain yang dapat mempengaruhi luas tanah karena faktor alam dan juga faktor manusia. Faktor alam yaitu perubahan bentuk tanah akibat dari alam sehingga berbeda dengan yang tertulis di Letter $C$ desa. Lalu dari faktor manusia, permasalahan karena kesalahan penujukan tanah dan pemasangan tanda batas yang tidak sesuai.

Saat melakukan pendaftaran tanah pemohon akan mengajukan permohonan pengukuran tanah, setelah itu Kantor Pertanahan mengukur tanah yang telah dipasang batas-batas yang telah dipasang oleh pemohon. Dalam pengukuran tanah petugas ukur menggunakan pengukuran kadastral yaitu sesuai dengan batas-batas yang sudah dipasang oleh pemohon dan disetujui oleh tetangga batas tanah. Dalam pelaksanaan pengukuran muncul permasalahan beda luas dan upaya yang dilakukan oleh Kantor Pertanahan memanggil para pihak yang berkepentingan dan kepala desa untuk hadir dan mengklarifikasi untuk mencari kebenaran perbedaan luas tanah. Setelah sepakat pemohon dan tetangga batas menandatangani surat pernyataan menerima perbedaan luas yang diketahui oleh kepala desa, surat pernyataan itu yang akan diguakan sebagai syarat untuk proses pendaftaran dapat dilanjutkan kembali. Setelah permasalahan telah diselesaikan maka peta bidang dapat diterbitkan dan dilanjutkan dengan sidang panitia adjudikasi yang akan menccokan hasil pengukuran dilapangan. Jika sudah dianggap lengkap maka dilakukan pengumuman yang akan ditempel di papan pengumuman yang ada di Kantor Pertanahan Kabupaten Semarang dan di Kantor Kelurahan yang ada di wilayah Kabupaten Semarang. Jika sudah tidak ada pihak yang keberatan maka Kantor Pertanahan Kabupaten Semarang menerbitkan sertipikat hak atas tanah kepada pemohon pendaftaran tanah untuk pertama kali.

\section{DAFTAR PUSTAKA}

\section{Buku}

Amiruddin, and Zainal Asikin. 2004. Pengantar Metode Penelitian Hukum. Jakarta: Grafindo Persada.

Fea, Dyara Radhite Oryza. 2016. Buku Pintar Mengurus Sertifikat Tanah Rumah \& Perizinannya. Yogyakarta: Buku Pintar.

Handoko, Widhi. 2014. Kebijakan Hukum Pertanahan. Yogyakarta: Thafa Media. . 2019. Dominasi Negara Terhadap Profesi Notaris. Bogor: PT.Roda Publika 
Kreasi.

Harsono, Boedi. 2003. Hukum Agraria Indonesia. Sembilan. Jakarta: Djambatan.

Lubis, Yamin, and Rahim Lubis. 2012. Hukum Pendaftaran Tanah. Bandung: Mandar maju.

Sangsun, Florianus SP. 2007. Tata Cara Mengurus Sertifikat Tanah. Jakarta: Visimedia.

Santoso, Urip. 2015. Pendaftaran Dan Peralihan Hak Atas Tanah. Keempat. Jakarta: Kencana.

\section{Artikel Jurnal}

Anhar. 2017. "Penerapan Asas Aman Dan Terbuka Terhadap Proses Pendaftaran Tanah (Studi Kantor Pertanahan Agraria Tata Ruang Lombok Barat).” Jurnal Jatiswara 32 (Nomor 3). https://doi.org/10.29303/jatiswara.v32i1.66.

Arief, Anggraeny. 2018. "Pelaksanaan Asas Kontradiktur Delimitasi Dalam Proses Pendaftaran Tanah Sistematis Lengkap." Jurisprudentie: Jurusan Ilmu Hukum Fakultas Syariah Dan Hukum 5 (1): 206. https://doi.org/10.24252/jurisprudentie.v5i2.5812.

Silviana, Ana. 2012. "Kajian Tentang Kesadaran Hukum Masyarakat Dalam Melaksanakan Pendaftaran Tanah.” Pandecta 7 (Nomor http://journal.unnes.ac.id/nju/index.php/pandecta.

\section{Undang-undang dan Peraturan}

Peraturan Kepala BPN RI Nomor 1 Tahun 2010 TentangStandarPelayanan Dan Pengaturan Pertanahan.

Peraturan Menteri Negara Agraria Nomor 2 Tahun 1996 Tentang Pengukuran Dan Pemetaan Untuk Penyelenggaraan Pendaftaran Tanah.

Peraturan Pemerintah Nomor 24 Tahun 1997 Tentang Pendaftaran Tanah.

Undang-Undang Dasar 1945.

Undang-Undang Nomor 5 Tahun 1960 Tentang Peraturan Dasar Pokok-Pokok Agraria. 